Jurnal Professional FIS UNIVED Vol. 4 No. 2 Desember 2017

\title{
REPRESENTASI ORIENTALISME DALAM FILM THE MAN WHO KNEW INFINITY
}

Oleh:

\author{
FILDZAH NABILAH ABRAR, ANIS ENDANG, HARIUS EKO SAPUTRA
}

\author{
Program Studi Ilmu Komunikasi Fakultas Ilmu-Ilmu Sosial \\ Universitas Dehasen Bengkulu
}

\begin{abstract}
Western unceasing production of the film with the character of the East that bad in it. To maintain the Orientalism of the West, adapt them to the times. Media of mass used is the mass media movie. Because of the film's West could easily represent Orientalism. The movie is popular and in demand, and can be watched by all ages. One Western movie that shows the representation of Orientalism is the movie The Man Who Knew Infinity. MovieThe Man Who Knew Infinity tells of the struggle of one of the Eastern scholars in the field of mathematics named Srinivasa Ramanujan. The movie represents the power and difference in social status between the West and the East. As well as how the Western view of the East or Orientalism.And to know the description or representation intentionally created by the movie, then the unambiguous approach to the Semiotic, to use Roland Barthes's model. So, this research want to find out how the meaning of denotation, connotation, and myth preformance of orientalism in the movie The Man Who Knew Infinity. Through the observation carefully and in collaboration with relevant documents, finally found the scene-the scene that can represent the orientalism in the film The Man Who Knew Infinity.The results showed that the representation of Orientalism that aredisplayed in the film this is a form of power of the West against the East. And the difference stastus social as well as position that are shown between the East and the West. Film director Matt Brown, accentuate how the West perceives the East. Although in the field of education of the East and the West have equality. But in class social status and position. The west and the East is not equal in the perspective of Orientalism.
\end{abstract}

Keywords: representation, orientalism, movie, education

\section{PENDAHULUAN}

Dalam kehidupan

manusia tidak pernah luput dari komunikasi. Proses interaksi berinteraksi sosial melalui simbol dan sistem pesan. Komunikasi pasti memiliki tujuan.Richard West \& Lyn H. Turner memberikan batasan bahwa komunikasi (communication) adalah proses sosial dimana individu-individu menggunakan simbol-simbol untuk menciptakan dan menginterpretasikan makna dalam lingkungan mereka (West \& Turner, 2007: 5).

Di era teknologi saat ini, kemajuan teknologi media komunikasi dengan berbagai jenis terus meningkat. Ini membawa pengaruh yang besar bagi masyarakat dunia. Banyak faktor yang membuat manusia untuk hidup serba instan, mewah, dan budaya barat yang telah masuk dari berbagai sisi. Hal ini menjadikan adanya pergeseran 
tata nilai moral dan budaya yang terjadi.

Beragam media komunikasi baik visual dan audiovisual pun hadir di masyarakat. Hal ini menjadi kebutuhan mendasar bagi manusia. Apalagi inovasi yang terus muncul dalam media komunikasi menjadi lebih canggih dari sebelumnya.

Film adalah alat untuk menyampaikan berbagai pesan kepada khalayak melalui sebuah media cerita. Film juga merupakan medium ekspresi artistik sebagai suatu alat bagi para seniman dan insan perfilman dalam rangka mengutarakan gagasan-gagasan dan ide cerita. Secara esensial dan substansial film memiliki power yang akan berimplikasi terhadap masyarakat (Wibowo, 2007:196).

Film muncul dari kreatifitas. Diperlukan ide-ide, konsep, teknis, dan memerlukan waktu dan proses yang panjang untuk menghasilkan karya yang berkualitas secara visual dan verbal. Pencarian ide atau gagasan ini dapat dilakukan dengan berbagai macam cara seperti mengangkat kisah dari biografi, novel, kisah nyata, cerpen, puisi, dongeng, atau bisa juga mengacu pada catatan pribadi. Film jugadiciptakan atau digunakanuntuk merepresentasikan tujuan tertentu. Seperti ingin menunjukkan kekuasan, politik, menanamkan ideologi, dan lain-lain.

Salah satu film yang diangkat dari biografi adalah "The Man Who Knew Infinity". Film "The Man Who Knew Infinity" menceritakan tentangSrinivasa Ramanujan seorang ahli Matematika yang berasal dari Madras, India. Dia dianugerahi otak jenius, dan menghabiskan waktunya untuk menulis berbagai macam teori Matematika. Karena terlalu cintanya pada angka, sang istrinya mengatakan bahwa Ramanujan lebih mencintai angka dibandingkan manusia.

Srinivasa Ramanujan adalah seorang India yang berusaha mendapatkan posisi terhormat di Cambridge University Trinity College dan menempatkan namanya pada serangkaian teori terobosan penting dalam penelitian ilmiah modern. Namun, hidupnya harus terhenti karena penyakit dan meninggal pada tahun 1920 di usia 32 tahun.

Film ini menggambarkan kepribadian seorang yang sangat hebat, kehadiran film ini begitu sangat menggugah bagaimana seorang India yang dikucilkan di Cambridge karena status Indianya. Karena Srinivasa Ramanujan berasal dari ras Indiadan tidak memiliki latar belakang pendidikan serta berasal dari keluarga miskin, maka apapun yang dilakukannya, seluas apapun pengetahuanya, ia selalu dianggap rendah dan diremehkan, dipandang sebelah mata dengan rasa jijik, serta tidak dianggap dan diragukan oleh Barat pada saat itu. Barat beranggapan bahwa tidak mungkin seseorang yang berasal dari Timur dan kelas rendah dapat melampui Barat khususnya dalam bidang pengetahuan salah satunya adalah matematika. Barat merasa bahwa merekalah yang lebih maju dan memiliki cara berpikir yang luas serta logis. Terlebih lagi Barat merasa bahwa Barat-lah yang lebih pantas mendapatkan pengakuan, bukan Timur. Oleh karena itu Ramajunan berusaha meyakinkan Barat pada saat itu, walaupun ia bukan berasal dari ras Barat dan tidak mempunyai latar belakang pendidikan. Ia mampu menemukan pemecahan masalah dalam bidang matematika, serta ia mampu menemukan rumus-rumus yang dianggap Barat tidak mungkin dipecahkan, dan menyelesaikan soal yang menurut Barat tidak mungkin untuk 
diselesaikan. Ramanujan berharap, pengakuan Barat terhadap dirinya dapat berdampak untuk temuannya. Agar dapat dipublikasikan secara luas dan bermanfaat dan digunakan bagi masyarakat serta ilmu pengetahuan khususnya matematika.

Orientalisme adalah pandangan Barat terhadap Timur. Sedangkan Orientalis adalah orang Barat yang meneliti tentang Timur, baik akademisi maupun seniman yang mempunyai tujuan tertentu. Film "The Man Who Knew Infinity" menunjukkan representasi orientalisme status sosial pendidikan. Barat menunjukkan kekuasannya terhadap Timur dan ketidak setaraan antara Barat dan Timur dalam bidang pendidikan melalui film tesebut.

Dengan latar belakang tersebut, maka peneliti tertarik untuk mengetahui lebih lanjut representasi Orientalisme yang disampaikan pada film “The Man Who Knew Infinity". Dari apa yang telah dipaparkan diatas, maka penulis ingin melakukan penelitian lebih lanjut dalam: REPRESENTASI ORIENTALISME DALAM FILM "THE MAN WHO KNEW INFINITY”.

Maka dalam penelitian ini bertujuan untuk mengetahui representasi Orientalisme dalam status sosial pendidikan di film "The Man Who Knew Infinity”.

\section{METODE PENELITIAN}

Penelitian yang digunakan menggunakan metode penelitian kualitatif. Penelitian kualitatif merupakan metode-metode untuk mengeksplorasi dan memahami makna yang oleh sejumlah individu atau sekelompok orang dianggap berasal dari masalah sosial atau kemanusiaan (Creswell, 2010: 4).Oleh karena itu penelitian ini juga disebut dengan penelitian yang bersifat Subjektif, dengan tujuan untuk mengekplorasi obyek penelitian sehingga nantinya akan didapatkan pesan dan maksud pada setiap bagian dari obyek yang diteliti.

Untuk mengkaji representasi Orientalisme yang terkandung pada film "The Man Who Knew Infinity",penelitian ini menggunakan metode analisis semiotik yang mengacu pada teori Roland Barthes, yang digunakan untuk menganalisis scenescene yang terdapat dalam film.

\section{Data Primer}

Data yang diperoleh langsung dari obyek penelitian yaitu dengan menganalisa terhadap objek penelitian yaitu film "The Man Who Knew Infinity”.

\section{Data Sekunder}

Data sekunder adalah data pendukung yang diambil melalui sumber lain seperti buku,arsip, dokumen resmi, tulisan -tulisan yang ada di situs internet dan sejenisnya yang dapat mendukung analisa penelitian tentang simbol -simbol dan pesan yang terdapat dalam sebuah penelitian.

\section{Teknik Pengumpulan Data}

Metode pengumpulan data yang digunakan adalah dokumentasi. Dokumentasi dilakukan dengan mengumpulkan scene-scene yang mengandung unsur Orientalisme dalam film "The Man Who Knew Infinity".Data-data yang terkumpul kemudian dianalisa dengan kerangka teori yang ada dan ditarik kesimpulan.

\section{Teknik Analisis Data}

Dalam kajian komunikasi, semiotika merupakan ilmu penting, sebab tanda-tanda (signs) merupakan basis utama dari seluruh komunikasi, karena dengan tanda-tanda manusia 
dapat melakukan komunikasi apapun dengan sesamanya (Sobur, 2013: 15). Semiotika adalah suatu ilmu atau metode analis untuk mengkaji tanda. Semiotika, atau dalam istilah Barthes, semiologi pada dasarnya hendak mempelajari bagaimana kemanusiaan (humanity) memaknai hal-hal(things). Memaknai berarti bahwa objek-objek tidak hanyamembawa informasi tetapi dalam hal mana objek-objek itu hendak berkomunikasi, tetapi juga mengkonstitusi sistem terstruktur dari tanda (Sobur, 2013: 15).

Semiotika sebagai suatu model dari ilmu pengetahuan sosial memahami dunia sebagai sistem hubungan yang memiliki unit dasar yang disebut "tanda", dengan demikian semiotika mempelajari hakekat tentang keberadaan tanda, baik yang dikonstruksikan dengan kata-kata atau simbol yang digunakan dalam konteks sosial (Sobur, 2004: 95).

Semiotika tentu tidak bisa dilepaskan dari pengaruh dan peran dari Charles Sander Pierce dan Ferdinand De Saussure. Keduanya meletakkan dasardasar bagi kajian semiotika. Analisis semiotika modern dikembangkan oleh Ferdinand De Saussure, ahli linguistik dari benua Eropa dan Charles Sanders Pierce, seorang filosof asal benua Amerika. Saussure menyebut ilmu yang dikembangkan- nya, "semiology" yang membagi tanda menjadi dua komponen yaitu penanda (signifier)yang terletak pada tingkatan ungkapan dan mempunyai wujud atau merupakan bagian fisik seperti huruf, kata, gambar, bunyi dan komponen yang lain adalah petanda (signified) yang terletak dalam tingkatan isi atau gagasan dari apa yang telah diungkapkan, serta sarannya bahwa hubungan kedua komponen ini adalah sewenang-wenang yang merupakan hal penting dalam perkembangan semiotik, sedangkan bagi Pierce, lebih memfokuskan diri pada tiga aspek tanda yaitu dimensi ikon, indeks, dan simbol (Sobur, 2004: 125).

Rolland Barthes (dalam Sobur, 2013: 69) menjelaskan bahwa tanda konotatif tidak sekedar memiliki makna tambahan namun juga mengandung kedua bagian tanda denotatif yang menelaah tanda secara bahasa sehingga menjadi landasan keberadaannya.

Representasi menurut Barthes menunjukkan bahwa pembentukan makna tersebut mencakup sistem tanda menyeluruh yang mendaur ulang berbagai makna yang tertanam dalamdalam di budaya Barat misalnya, dan menyelewengkannya ke tujuan-tujuan komersil. Hal ini kemudian disebut sebagai struktur (Danesi, 2010: 28).

Sehingga, dalam semiotik Barthes, proses representasi itu berpusat pada makna denotasi, konotasi, dan mitos. Ia mencontohkan, ketika mempertimbang-kan sebuah berita atau laporan, akan menjadi jelas bahwa tanda linguistik, visual dan jenis tanda lain mengenai bagaimana berita itu direpresentasikan (seperti tata letak / lay out, rubrikasi, dsb) tidaklah sesederhana mendenotasikan sesuatu hal, tetapi jugamenciptakan tingkat konotasi yang dilampirkan pada tanda (Bignell, 1997: 16.). Barthes menyebut fenomena ini membawa tanda dan konotasinya untuk membagi pesan tertentu sebagai penciptaan mitos.

Dari elemen Barthes dapat terlihat bahwa tanda denotatif (3) terdiri atas penanda (1) dan petanda (2). Akan tetapi pada saat bersamaan tanda denotatif adalah juga penanda konotatif (4). Dengan kata lain, hal tersebut merupakan unsur material: hanya jika anda mengenal tanda "singa", barulah konotasi seperti harga diri, kegarangan, 
dan keberanian menjadi mungkin (Sobur, 2013: 69)

a) Makna Denotasi:

Makna denotasi adalah makna awal utama dari sebuah tanda, teks, dan sebagainya (Danesi, 2010: 274).Makna ini tidak dibisa dipastikan dengan tepat, karena makna denotasi merupakan generalisasi. Dalam terminologi Barthes, denotasi adalah sistem signifikansi tahap pertama. Elemen-elemen yang diperhatikan dalam analisis gambar atau visual menurut Shelby dan Cowdery (1995: 57-58):

Selain elemen-elemen diatas, elemen lainnya yang perlu diperhatikan adalah:

1) Aural Signs (Speech)

Bignell (1997:

menekankan pentingnya melakukan analisis unsur dialog dalam teks sinetron. Bahwa salah satu karakteristik sinetron adalah penekanan pada dialog, alihalih aksi (Burton, 2005: 255; Hall, 2013: 368). Aktor Thompon (dalamStam dkk, 1992: 62)menyebutkan kaitannya dengan dialog bahwa istilah external diegetic soundadalah dialog yang disampaikan oleh aktor dan disadari oleh aktor lain, dan internal diegetic soundadalah dialog yang diucapkan melalui pikiran dan tidak didengar oleh aktor lain, namun ditangkap oleh penonton.

2) Sounds and Music

Musik dan bunyi merupakan unsur penting dalam teks film dan televisi. Jenis musik atau bunyi yang digunakan untuk mempertegas emosi karakter disebut sebagai nondiegetic sound (Stam dkk, 1992: 62). Musik dan permainan bunyi berperan untuk menarik minat penonton agar tetap berada di depan layar, menekankan emosi yang ditampilkan oleh para aktor, serta mengarahkan respon emosi dan perasaan penonton terhadap adegan yang sedang mereka saksikan (Berger, 2014: 12; Bignell, 1997: 161).

3) Visual Signs (Images)

Salah satu elemen penting dalam analisis semiotika adalah images yang ditampilkan. Walaupun tanda-tanda visual yang ditampilkan terlihat bermakna denotatif, namun keterlibatan crew dan kehadiran kamera dalam proses produksi membuatnya mengandung makna-makna konotatif yang dapat diperoleh dari latar (setting) tempat berlangsungnya adegan, ornamen pendukung latar, pakaian yang dikenakan aktor, mimik wajah para aktor, atau aktor yang dipilih untuk memainkan peran tersebut (Bignell, 1997: 158).

b) Makna Konotasi:

Dalam kerangka Barthes, konotasi identik dengan operasi ideologi, yang disebutnya sebagai "mitos" dan berfungsi untuk mengungkapkan dan memberikan pembenaran bagi nilai-nilai dominan yang berlaku dalam suatu periode tertentu(Budiman dalam Sobur, 2013: 71). Konotasi 
merupakan makna-makna kultural yang muncul atau bisa juga disebut makna yang muncul karena adanya konstruksi budaya sehingga ada sebuah pergeseran, tetapi tetap melekat pada simbol atau tanda tersebut (Kriyantono, 2007: 268).Petanda ini dapat pula disebut fragmen ideologi. Dan dapat dikatakan bahwa "ideologi” adalah bentuk petanda konotasi dan "retorika" adalah bentuk konotasi (Barthes, 1967: 91-92).Tahap pemaknaan konotasi dilakukan dengan kode ideologi yang merupakan rangkaian dari codes of television fiction Jonathan Bignell

\section{HASIL PENELITIAN DAN PEMBAHASAN}

Scene 1

Adegan pertama yang dipilih peneliti adalah adegan dimana Ramanujan sedang mencari pekerjaan. Dalam perjalanan nya mencari pekerjaan sembari membawa buku catatan yang berisi rumus-rumus serta temuan-temuan matematika yang diciptakan sendiri oleh Ramajunan, Ramajunan mengalami penolakan tanpa adanya uji coba terhadap kemampuan Ramajunan. Ramajunan mendatangi sebuah kantor yang dipimpin oleh orang Barat. Ramajunan membutuhkan sebuah pekerjaan untuk menghidupi istrinya. Ketika ia menunjukkan buku yang berisi temuantemuannya, Ramajunan ditolak dan diusir karena temuan yang ia miliki tidak jelas asal usulnya. Karena Ramajunan adalah seorang otodidak, semua pengetahuan yang ia miliki didapat secara otodidak bukan dari pendidikan formal pada umunya.

\section{Denotasi}

Terlihat dua orang yang sedang melakukan percakapan di dalam sebuah
(1997: 161). Dijelaskan Himawan Pratista (2008: 1),sebuah film terbentuk dari dua unsur, yaitu unsur naratif dan unsur sinematik. Unsur naratif berhubungan dengan aspek cerita atau tema film. Setiap film cerita tidak mungkin lepas dari unsur naratif dan setiap cerita pasti memiliki unsur-unsur seperti tokoh, masalah, konflik, lokasi, waktu, serta lainnya. Seluruh elemen tersebut membentuk unsur naratif secara keseluruhan. Aspek kaualitas bersama unsur ruang dan waktu merupakan elemen-elemen pokok pembentuk suatu narasi.

kantor. Pria dengan pakaian lusuh berwarna kuning dipadukan dengan rompi coklat adalah Ramajunan. Sedangkan pria dengan pakaian rapih dan bersih, adalah pimpinan di kantor tersebut. Pada gambar pertama dan ketiga,Close-up digunakan untuk menampilkan mimik wajah dan baju yang dikenaakan. Raut wajah Ramajunan terlihat memelas, sedangkan pimpinan tersebut mengangkat wajahnya dan terlihat angkuh. Sedangkan medium shot digunakan pada gambar ketiga, untuk memperlihatkan setting yang ada.

\section{Konotasi}

Percakapan yang dilakukan oleh Ramajunan dan pimpinan kantor tersebut menandakan bahwa Ramajunan sedang memohon untuk mendapatkan pekerjaan. Terlihat dari raut wajah yang ditunjukkan oleh Ramajunan yang memelas terhadap pimpinan tersebut. Akan tetapi pimpinan tersebut menolak Ramajunan karena Ramajunan adalah seorang pengangguran yang tidak berpendidikan. Walaupun Ramajunan telah menunjukkan hasil riset yang telah dilakukannya sendiri. Akan tetapi pimpinan tersebut menolak Ramajunan 
dengan wajah yang diangkat, menandakan keangkuhan dan kesombongan.

Kajian orientalisme mempunyai karakter khusus, karena Orientalisme merupakan bagian yang tidak terpisahkan dari pemahaman Orientalisme itu sendiri, karena Orientalisme adalah suatu kajian yang mempunyai ikatan sangat- erat hubungannya dengan kolonial Barat, khususnya kolonial Inggris. Orientalisme merupakan bentuk kajian yang dianggap paling potensial dalam politik dunia Barat untuk melawan Timur (Buchori, 2006: 14-16).

Pimpinan di kantor tersebut merupakan salah satu dari kolonial Barat dan berasal dari Inggris. Sedangkan Ramajunan merupakan orang Timur. Karena kekuasan yang dimiliki oleh pimpinan kantor tersebut. Ia melawan Ramajunan dengan penolakan yang beralasan bahwa Ramajunan tak berpendidikan dan bergelar. Ia mengusir Ramajunan dari kantornya, sambil berkata

"Kalian ini sama saja. Sekarang, keluar. Sekarang!”

Perkataan nya tersebut, menandakan bahwa banyak orang-orang Timur lainnya yang datang melamar pekerjaan di tempatnya. Pimpinan tersebut beranggapan bahwa semua orang Timur itu sama saja. Walaupun Ramajunan mempunyai pengetahuan yang luas tentang matematika. Tetap saja Ramajunan ditolak, dan mendapatkan perlakuan kasar yang ditunjukkan dari perkataan pimpinan tersebut. Karena ia yang memiliki kekuasaan maka, ia melawan kenyataan bahwa Ramajunan memiliki kepintaran dengan cara menolaknya untuk bekerja di kantornya

\section{Scene 2}

Keesokan paginya Ramajunan melanjutkan usahanya untuk mendapatkan sebuah pekerjaan. Ia melamar disalah satu kantor, yang di dalamnya banyak pekerja India. Di sana Ramajunan bertemu dengan Narayana. Salah satu orang India yang bekerja cukup lama dengan orang Inggris. Karena Narayana sudah cukup lama bekerja di kantor tersebut, Narayana berani merekrut Ramajunan sebagai juru tulis di kantor tersebut setelah melihat temuan yang dimiliki oleh Ramajunan.

\section{Denotasi}

Pada gambar tersebut terlihat bahwa Ramajunan dipandang dengan rasa jijik oleh Sir Francis. Dengan raut muka alis diangkat satu, dan salah satu mata dipicingkan. Serta kepala yang dimiringkan sedikit ke kiri. Sedangkan close up dipergunakan untuk memperjelas mimik wajah Sir Francis pada gambar ketiga. Long shot digunakan agar terlihat bagian belakang kantor, yang menunjukkan bahwa pegawai di kantor tersebut sedang bekerja dan mereka merupakan orang Timur. Dilihat dari tanda putih yang ada di kening mereka.

\section{Konotasi}

Ketika Ramajunan menunjukkan temuannya pada Narayana, terlihat bahwa dibelakang mereka sedang ada pegawai kantor lainnya yang sedang bekerja. Dan pekerja yang bekerja dikantor tersebut yang tampak pada gambar 1 mereka semua adalah orangorang Timur. Temuan Rmajunan langsung disambut baik oleh Narayana, akan tetapi sifat yang ditunjukkan oleh Sir francis berbanding terbalik dengan Narayana. Pandangan Sir Francis terhadap Ramajunan merupakan bentuk ketidak sukaan terhadap Ramajunan. Karena Ramajunan terlihat lusuh dan miskin, serta tidak berpendidikan.

Jika gagasan-gagasan resialisme imperial membuka peluang bagi para 
Orientalis untuk memisahkan Timur dari kekuatan-kekuatan yang maju dan beradab dan jika Timur "klasik" justru menjustifikasi sang Orientalis dan pandangan rendahnya terhadap manusiamanusia Timur modern, maka Orientalisme laten juga mendorong tumbuhnya konsepsi tentang laki-laki Timur yang aneh dan hina serta dipandang dengan rasa jijik dan takut. Laki-laki Timur dianggap terisolasi dari totalitas masyarakat dimana ia hidup. (Said, 2010: 318-319). Seperti yang dilakukan Sir Francis yang memandang Ramajunan dengan jijik serta menganggap bahwa Ramajunan adalah seorang gelandangan.

Sebagai aparatus kebudayaan, Orientalisme merupakan sejenis agresi, kegiatan, penilaian, bahkan dapat dikatakan sebagai suatu "kebenaran” dan pengetahuan: "Timur diciptakan untuk Barat” (Said, 2010: 314-315). Timur diciptakan untuk Barat, terlihat dari pekerja yang berada di dalam scene tersebut. Di dalam scene tersebut tidak terlihat adanya pegawai yang berasal dari Barat. Satu-satunya orang Barat yang terlihat di dalam scene tersebut adalah Sir Francis, yang merupakan pimpinan di kantor tersebut. Sedangkan orang-orang Timur yang berada di dalam scene tersebut adalah para pegawai yang bekerja untuk Sir Francis. Penilaian juga dilakukan oleh Sir Francis ketika mellihat cara berpakaian Ramajunan. Ia menilai bahwa Ramajunan tidak pantas bekerja disini, bahkan dia diusir oleh Sir Francis. Akan tetapi karena Narayana berasal dari ras yang sama dan tidak meragukan Ramajunan. Maka Narayana mempertahankan Ramajunan untuk tetap bekerja disitu sebagai juru tulis.

Timur tetaplah Timur tak peduli apapun kasus yang dialaminya dan tak peduli gaya atau teknik apapun yang digunakan untuk memaparkannya (Said, 2013: 395). Meskipun didalam gambar 4
Ramajunan menghitung tanpa menggunakan sempoa. Yang ditunjukkan lewat percakapan antara Ramajunan dan Narayana

Narayana: Kenapa tak gunakan sempoa?

Ramajunan: Lebih cepat dengan otakku.

Narayana: Mengesankan. Jika Sir Francis kemari, pura-puralah menggunakannya. Kulihat kau bekerja dengan rumusmu sendiri.

Kertas adalah komoditas penting di sini. Ada bertumpuk-tumpuk di bawah laci.

Ramajunan: Terima kasih, Pak.

Narayana: Sampai ketemu malam nanti.

Meskipun Ramajunan merasa lebih cepat menggunakan otaknya dari pada menggunakan alat bantu. Tetap saja jika terlihat oleh Sir Francis, Ramajunan akan mendapatkan teguran. Karena Sir Francis meragukan Ramajunan yang dinilai dari cara berpakaian, serta latar belakang pendidikan yang tidak dimiliki oleh Ramajunan. Oleh karena itu Narayana memberitahukan Ramajunan untuk tetap sigap ketika Sir Francis datang dengan berpura-pura menggunakan alat bantu hitung. Meskipun Ramajunan cepat berhitung menggunakan otaknya, akan tetapi karena Ramajunan adalah seorang pegawai di kantor tersebut. Dan Sir Francis adalah pimpinan di kanor tersebut, Ramajunan tidak boleh terlihat unggul dari Sir Francis. Karena Ramajunan adalah pegawai dan orang Timur, dan pegawai tidak boleh terlihat lebih unggul dari pimpinan yaitu Sir Francis yang berasal dari Barat.

Tidak hanya itu jika ada unsurunsur Timur yang buruk (seperti penjahat-penjahat, orang-orang gila, kaum wanita, dan orang-orang miskin) yang memiliki perbedaan identitas dengan unsur-unsur Barat yang baik, 
maka Timur tak jarang dijabarkan sebagai sesuatu yang sangat asing (Said, 2010: 318-319). Seperti Ramajunan yang tidak berpendidikan dan terlihat seperti gelandangan di mata Sir Francis. Karena Timur tetaplah timur, yang harus berada di bawah Barat. Yang ditunjukkan oleh Narayana, Ramajunan, dan pegawai yang terlihat pada gambar 1. Dan Barat tetaplah Barat, yang berada diatas, yang ditunjukkan oleh Sir Francis. Yang merupakan satu-satunya orang Barat di dalam scene tersebut, dan merupakan pimpinan di kantor tersebut.

Maka dari itu, Barat selalu menjadikan nilai-nilai Timur yang baik dan yang buruk untuk memenuhi kepentingan mereka di Timur (Said, 2010: 317). Kantor yang dipimpin oleh Sir Francis berada di Timur. Kepentingan Barat terlihat dari bawahan yang ada di dalam kantor tersebut. Mereka mencari orang-orang Timur yang baik dan pantas untuk kepentingan mereka. Lalu orang-orang Timur tersebut diperkerjakan di kantor mereka yang berada di Timur.

\section{Scene 3}

Pertemuan Ramajunan dan Narayana di malam hari, membuat Ramajunan berani untuk mengambil langkah atas temuannya. Narayana memberikan dukungan atas pengetahuan yang dimiliki oleh Ramajunan. Dan memberikan saran untuk mengirimkan surat ke Inggris. Narayana meyakinkan Ramajunan bahwa ia akan berada dipuncak, jika ia berhasil membawa pengetahuannya ke Inggris dan mempublikasikan temuannya tersebut.

\section{Denotasi}

Tampak pada gambar 1 dan 2 Ramajunan dan Narayana bertemeu di depan kantor dan melakukan percakapan. Mereka mengenakan pakaian putih. Narayana dengan posisi berdiri menghadap Ramajunan. Dan
Ramajunan sedang duduk di kursi menghadap ke arah Narayana.

\section{Konotasi}

Narayana sedang meyakinkan Ramajunan bahwa hasil temuannya harus dipublikasikan. Narayana yakin bahwa Ramajunan setara dengan Barat dalam ilmu pengetahuan. Dan Barat harus tahu, bahwa ada orang Timur yang kepintaran nya menyamai kepintaran Barat. Posisi berdiri Narayana saat mengobrol seolah-oleh menegaskan perkataannya. Sedangkan Ramajunan dengan posisinya yaitu duduk di kursi, akan lebih menyimak apa yang dikatakan oleh Narayana. Narayana mengatakan

"Madras. Tahukah kau nama turunan dari Mandarajya? "Domain orang bodoh."Ada dunia di luar sana. Dan di sana ada Inggris.karya ini terlalu penting untuk kau bawa mati harus dipublikasikan. Jika kau seorang India berada dipuncak bersama rumus-rumus ini, maka orang Inggris sekalipun mereka menjajah kita, pasti tahu bahwa keunggulan kita sepadan dengan mereka".

Said

(2010: 503508)menyebutkanadanya dua faktor yang melatarbelakangi kejayaan Orientalisme selama ini. Yang pertama, adalah reproduksi Timur, sedangkan yang kedua adalah konsumerisme (di) Timur. Sistem reproduksi semacam ini pada akhirnya membuat seorang cendekiawan Timur mau tidak mau harus menggunakan pendidikan Barat untuk merasa lebih unggul dari kaumnya sendiri dengan alasan ia mampu "menguasai" sistem Orientalis. Itulah yang ingin ditunjukkan oleh perkataan Narayana terhadap Ramajunan. Karena Madras domain orang bodoh, agar terlihat lebih unggul atau setara dengan orang Inggris. Maka Ramajunan harus membawa temuannya tersebut ke Inggris, agar orang Inggris tahu bahwa 
ada orang Madras yang menyamai mereka. Meskipun Inggris menjajah mereka, tetapi mereka tetap sepadan dalam ilmu pengetahuan dengan Inggris.

\section{Scene 4}

Setelah bertemu dengan Narayana, akhirnya Ramajunan memberanikan diri mengirim surat ke universitas Cambridge, yang ditujukan kepada Hardy. Tetapi Hardy tidak mempercayai surat tersebut, karena surat tersebut berasal dari Madras, India. Kemudian untuk meyakinkan dirinya bahwa surat itu bukan lah tipuan dari temannya, maka Hardy menemui temannya yaitu Littlewood

\section{Denotasi}

Pada gambar kedua terlihat Littelwood duduk dengan sopan di kursi. Dan Hardy duduk dengan kaki diletakkan diatas meja. Dengan posisi kedua tangan dilipat kebelakang. Dan mulut Hardy menghisap tembakau melalui pipa cangklong, serta Hardy menutupi separuh mukanya dengan menggunakan topi.

\section{Konotasi}

Hardy dan Littleewood sedang melakukan percakapan. Mereka berdiskusi tentang surat yang dikirimkan dari Madras, India. Posisi duduk Littlewood lebih terlihat tenang dibandingkan Hardy. Posisi duduk Hardy dengan kaki diatas meja memperlihatkan keangkuhan, dan kesombongan, di lengkapi dengan pipa cangklong menambah kesan elite. Hardy merasa bingung dengan seseorang yang bernama Ramanujan. Seperti yang terlihat dari percakapan antara Hardy dan Littlewood:

Hardy: "Littlewood, bisa kita bicara?"

Littlewood: "Ya, tentu.

Integral. Deret hitung tak terhingga. Hanya Tuhan yang tahu selanjutnya. Maaf. Aku lupa kau tak percaya Tuhan."

Hardy: "Benar."

Littlewood: "Jika orang ini ternyata jenius, kau harus pertimbangkan lagi."

Hardy: "Dia pasti jenius.

Siapa yang punya imajinasi

menciptakan itu semua?"

Littlewood:“Aku agak tersanjung, kau sempat

mengira aku pembuatnya. Dua deret tak terhingga ini lebih memukau."

Hardy: "Ya. Mengalahkanku telak. Tak pernah kulihat hal seperti ini. Ini bersifat samar. Aku akan pertaruhkan deret hipergeometrik. Littlewood kita yang hebat, bingung."

Littlewood:"Dia sekelas Hobbs, menurutku. "Tak punya pengalaman, saya hargai apapun saran yang Anda berikan. "Hormat saya, S. Ramanujan." "S" Singkatan dari apa?

sendiri."

Hardy: Kau bisa tanyakan

Littlewood: "Kau ingin mengundangnya kemari?”

Hardy: “Tidak, tidak, tidak.Jauh lebih baik, biarkan ia membusuk di kantornya di Madras?"

Orientalisme memiliki keterbatasan-keterbatasan tersendiri justru ketika mereka tidak mampu mengungkapkan kebenaran Timur yang sebenarnya. Keterbatasan yang juga merupakan kelemahan ini bersumber dari peremehan, pemahaman yang berbeda, dan pelepasan predikat manusiawi yang dilakukan orientalisme terhadap budaya, rakyat, atau kawasan geografis lain yang dianggap berbeda dan asing (Said, 2010: 164).

Dari gaya berbicara Hardy, Hardy tidak mau mengakui bahwa Ramajunan mengalahkan nya dalam deret hitung. Karena Hardy merasa bahwa merekalah yang paling hebat dan benar. Serta memiliki latar belakang 
pendidikan formal yang tinggi. Hardy merasa walaupun Ramanujan memiliki kemampuan melebihinya sehingga Ramajunan bisa mengalahkan kemampuannya dalam deret hitung. Akan tetapi karena Ramanujan tidak memiliki latar belakang pendidikan, dan berasal dari India. Maka Hardy meremehkan kemampuan Ramajunan dalam bidang matematika. Dan menganggap bahwa Ramajunan bukanlah apa-apa dibandingkan dengan mereka yang hebat. Hardy bertindak seperti itu, karena ia tidak mau mengakui kebenaran yang sebenarnya. Bahwa Ramajunan lebih unggul dibandingkan mereka.

Dari sini kita bisa melihat bagaimana mereka seolah-olah memiliki masalah tersendiri untuk menghadapi imajinas-imajinasi mereka tentang Timur (Said, 2010: 299). Seperti yang dikatakan oleh Hardy:

Littlewood: "Kau

ingin

mengundangnya kemari?”

Hardy: "Tidak, tidak, tidak.Jauh lebih baik, biarkan ia membusuk di kantornya di Madras!"

Hardy menolak untuk mengundang Ramajunan ke universitas Cambridge. Hardy lebih memilih untuk mengabaikan Ramajunan, dan membiarkan Ramajunan tetap di Madras. Penolakan Hardy termasuk kedalam bentuk imajinas atau pemikirannya tentang Timur. Hardy berpikir jika ia mengakui kepinttaran Ramajunan, maka ia akan kalah terhadap Ramajunan. Karena Hardy beranggapan bahwa merekalah yang paling hebat.

\section{Scene 5}

Karena rasa penasaran hardy dan Littelwood, maka merekapun mengundang Ramajunan untuk datang ke universitas Cambridge, di Inggris. Kedatangan Ramanujan pun disambut hangat oleh Littelwood.

\section{Denotasi}

Gambar di dalam scene 7 menggunakan medium shot untuk menampilakan kemegahan dari universitas cambridge, Inggris. Gambar dimulai dari gerbang utama, lalu ketika Littelwood dan Ramajunan berjalan masuk, dan pada gambar ketiga diambil gambar dari samping Ramajunan.

\section{Konotasi}

Ketika Ramajunan sampai dan berada di universitas Cambridge, Ramajunan disambut hangat oleh Littlewood. Ketika Ramajunan dan Littelwood ingin masuk ke dalam. Tibatiba Ramajunan bertanya kepada Littlewood:

bersama?”

Ramajunan: "Kita jalan

Littelwood: "Ya. Pengaruh yang sengaja dibuat. Jangan merasa terintimidasi”

Pertanyaan Ramajunan serta jawaban yang diberikan oleh Littlewood. Menunjukkan adanya kesengajaan atas kesengajaan yang dibuat Barat terhadap Timur. Mereka beranggapan bahwa:

"Oh, East is East, and West is West, and never the twain shall meet."

(Oh, Timur Tetaplah Timur, dan Barat tetaplah Barat, dan keduanya tidak akan pernah bertemu) (Kipling, dalam jurnal Jouhki2006)

Karena Barat menanamkan pemikiran tersebut, maka Ramajunan berpikir ia sebagai orang Timur tidak pantas untuk berjalan bersama Littlewood yang merupakan orang Barat. Bangunan universitas Cambridge sengaja disorot agar kemegahan kampus tersebut terlihat. Gambar Universitas diambil dari depan gerbang, ketika Ramajunan dan Littlewood berkenalan. Bangunan sengaja disorot untuk memperlihatkan kemegahan serta 
bangunan tersebut cocok untuk kalangan elite. Gambar pertama disorot dari depan, menunjukkan bahwa kampus tersebut besar. Lalau gambar selanjutnya, diambil ketika Ramajunan dan Littlewood mulai memasuki gerbang, terlihat kemegahan kampus tersebut. Gambar terakhir, diambil ketika Ramajunan terpesona dengan bangunan kampus yang dilihatnya yang tampak luas.

Dengan kemegahan yang dilihatnya Ramajunan semakin berpikir bahwa ia tidak pantas berjalan beriringan dengan Littlewood. Meskipun Ramajunan berjalan beriringan dengan Littlewood, tetap terlihat perbedaan antara Ramajunan dan Littlewood, Littlewood adalah salah satu profesor di universitas Cambridge dan Ramajunan adalah seorang India yang diundang ke universitas. Itulah mengapa, Ramajunan mengajukan pertanyaan kepada Littlewood. Karena Ramajunan merasa bahwa Timur tetaplah Timur, dan Barat tetaplah Barat dengan ke elit-tan nya.

\section{Scene 6}

Jika Ramajunan disambut hangat oleh Littlewood, maka berbanding terbalik dengan para profesor yang berada di dalam ruangan. Mereka bahkan mencekal kedatangan Ramajunan, mereka juga menilai sebelum melihat atau menguji kemampuan yang dimiliki oleh Ramajunan. Tetapi Hardy mencoba menenangkan mereka, dengan harapan bahwa surat yang dikirim oleh Ramajunan tersebut bukanlah hasil pemikirannya. Dari sinilah dimulainya kerjasama antara Hardy dan Ramajunan.

\section{Denotasi}

Pada gambar 1, terlihat para ilmuwan Barat sedang berkumpul dalam satu ruangan. Lalu pada gambar 2, terlihat Ramajunan menyodorkan tangan untuk bersalaman. Dan kemudian gambar 3, Hardy menundukkan kepala dan mengabaikan tangan Ramajunan yang ingin bersalaman.

\section{Konotasi}

Para ilmuwan Barat yang sedang berkumpul, mereka sedang melakukan diskusi atas Ramajunan. Mereka menolak kedatangan Ramajunan, karena ia adalah seorang India. Howard dan Profesor mengatakan:

Howard: Kurasa ini tindak kriminal.Kita membawa orang India ini dengan

biaya besar dan lihat apa yang terjadi.

Profesor: Bukan soal Ramjin, siapapun namanya, adalah orang India. Kita sudah punya pelajar India di sini. Hanya saja tak ada yang terdidik untuk berbicara. Memalukan.

Perkataan Howard dan profesor menunjukkan ketidaksukaan mereka terhadap India. Setiap perilaku masyarakat pribumi (Timur), meskipun ia hidup di zaman modern harus di girirng kembali ke asalnya (Said, 2010: 359).Bersama dengan bangsa-bangsa lain yang disebut terbelakang, merosot, tak beradab, dan dungu, bangsa-bangsa Timur sering kali dilihat dalam satu kerangka yang dibangun atas dasar determinisme biologis dan pengajaran moral politis (Said, 2010: 318-319). Howard mengatakan bahwa yang dilakukan oleh Hardy merupakan suatu tindak kriminal. Karena mendatangkan seorang India ke universita yang bergengsi dan diperuntukan untuk orangorang elit. Kemudian profcsor pun bermaksud untuk tidak menerima Ramajunan dikampus tersebut, karena mereka sudah memilik pelajar India yang menurutnya tidak terdidik untuk berbicara dan itu dianggap memalukan sama saja ia menganggap bahwa pelajar India tersebut merosot, tak beradab, dan dungu. Meskipun Ramajunan adalah seorang India yang memiliki 
kemampuan luar biasa dalam bidang matematika. Tetapi tetap saja, profesor merasa bahwa Ramajunan harus tetap berada di tempat asalnya yaitu di Madras, India. Dan pelajar India yang berada di universitas tersebut, juga harus dibawa pulang ke asalnya. Mereka merasa bahwa Ramajunan dan pelajar India tersebut, tidak pantas berada di universitas Cambridge yang domain orang-orang Barat dan elit, serta terdidik dan universitas tersebut tidak pantas untuk mereka orang-orang Timur. Mereka merasa bahwa orang-orang Timur yang berada di Barat harus digiring kembali ke Timur, ke tempat asal mereka.

Ketika Hardy pertama kali bertemu dengan Ramajunan, Hardy tidak menyambut niat baik Ramajunan untuk berjabat tangan.

\section{Scene 7}

Dalam perjalanan nya untuk sebuah publikasi, Ramajunan diharuskan mengikuti beberapa matakuliah dengan tujuan agar Ramajunan bisa mengikuti metode yang dimiliki oleh Barat.

\section{Denotasi}

Medium shot digunakan pada gambar 1, untuk memperlihatkan bahwa mereka sedang melakukan pembicaraan bertiga. Sedangkan close-up digunakan pada gambar kedua, untuk memperjelas alas kaki yang digunakan oleh Ramajunan.

\section{Konotasi}

Hardy dan Littlewood sengaja mengundang Ramajunan ke ruangan Hardy untuk membicarakan tata cara yang harus diikuti oleh Ramajunan. Akan tetapi sebelum Hardy mulai berbicara, Hardy terkejut melihat alas kaki yang digunakan oleh Ramajunan berupa sendal.

"Orientalis mampu meniru manusia Timur, tanpa manusia Timur bisa menirunya” (Said, 2010: 247).
Itu terlihat dari alas kaki yang digunakan oleh Ramajunan, seharusnya Ramajunan menggunakan sepatu agar terlihat sama seperti Barat. Akan tetapi Ramajunan tidak bisa meniru gaya berbusana Barat yang modern, karena Ramajunan tidak terbiasa dengan gaya tersebut. Meskipun Ramajunan mencoba meniru gaya berbusana Barat yang modern, tetapi tetap saja tidak bisa sama seperti Barat. Orientalis ingin menunjukkan, Ramajunan tidak bisa mengikuti Barat dalam hal berbusana. Apalagi dalam hal pendidikan, meskipun Ramajunan bisa mengikuti pendidikan formal di universitas Cambridge. Tetap saja Ramajunan tidak bisa mengikuti cara berpikir Barat yang Rasional. Karena jika Ramajunan mengikuti metode formal maka akan lebih mudah untuk Hardy meniru temuan Ramanujan dan akan bermanfaat bagi Barat di masa depan.

Ada dua metode yang digunakan Orientalisme untuk menyuguhkan Timur ke dunia Barat. Yang pertama dengan menggunakan ilmu pengetahuan modern yang diseminatif, melalui kajiankajian intelektual Orientalis, universitasuniversitas, masyarakat-masyarakat profesional, organisasi-organisasi eksplorasi geografis, dan industriindustri penerbitan. Metode kedua yang digunakan orientalisme untuk menyuguhkan Timur ke Barat adalah melalui konvergensi(Said, 2010: 339341).

Tetapi dalam film ini, metode yang digunakan untuk menyuguhkan Timur ke dunia Barat adalah metode yang pertama. Yaitu dengan menggunakan ilmu pengetahuan yang modern. Ramajunan diundang untuk datang ke Inggris karena teori-teori serta analisis matematikanya, agar Hardy bisa memastikan bahwa Ramajunan bukanlah seorang pembohong. Karena Hardy yang mengundang Ramajunan untuk datang 
ke Inggris, serta Hardy berusaha meyakinkan para penentang Ramajunan (scene 8). Hardy harus bisa membuktikan bahwa, undangannya terhadap Ramajunan tidak sia-sia. Begitulah cara Hardy menyuguhkan Ramajunan ke universitas Cambridge.

Hardy: "Baik. Ramanujan, kami putuskan, demi kebaikan semua orang kau harus ikuti beberapa kuliah."

Ramajunan: "Tapi saya ke sini untuk publikasi"

Hardy: "Ya, di saat yang tepat, semoga. Tapi pertama kami perlu pembuktian hasil karyamu. Tak ada yang perlu dicemaskan. Ini cuma soal yang membiasakanmu dengan metode formal yang akan bermanfaat bagi pekerjaan kita di masa depan. Maksudku, kita butuh bahasa umum. Kau tak berharap kami bercakap denganmu dalam bahasa Tamil."

Ramajunan: "Tidak. Tapi Anda berharap saya menggunakan bahasa Inggris."

Hardy: "Begitulah. Jadi, masih banyak waktu untuk publikasi”.

Meskipun para cendikiawan Barat sadar akan adanya manusia-manusia Timur yang modern, Timur tetaplah dianggap sebagai objek yang perlu ditelliti dan direkonstruksi oleh sang Orientalis. Tidak hanya itu, Timur seperti ini juga dilihat sebagai sejenis status budaya yang rendah dan pengetahuan yang bermanfaat bagi kegiatan sang orientalis, yang menganggap dirinya sebagai hakim superior, manusia terpelajar, dan ego budaya yang kuat (Said, 2010: 320).

Meskipun Hardy sadar akan kemampuan yang dimiliki oleh Ramajunan dalam matematika, akan tetapi Ramajunan tetap harus mengikuti beberapa kelas agar Ramajunan bisa mengikuti cara berpikir Barat yang mereka anggap rasional. Hardy merasa bahwa mereka adalah orang-orang yang terdidik, maka dari itu Ramajunan harus mengikuti kelas mata kuliah agar terlihat apakah Ramajunan benar-benar memiliki kemampuan tersebut atau cuman berpura-pura. Karena rasa penasaran yang tinggi, dan sifat superioritas. Maka Hardy ingin meneliti kebenaran pengetahuan Ramajunan. Serta teoriteori yang ditemukan oleh Ramajunan agar bermanfaat bagi dirinya dan universitas.

Untuk mendukung usaha ini, mereka dilengkapi dengan berbagai fasilitas, seperti alat percetakan,sekolahsekolah, universitas, rumah sakit, dan sebagainya untuk dipersembahkan kepada Timur. Tentu saja, pranatapranata ini, sekilas, telah memberikan sumbangang besar bagi kesejahteraan kawasan Timur. Karena tujuan utamanya adalah untuk menguasai Timur (Said, 2010: 458-460). Ramajunan diberikan pendidikan formal secara gratis, dan diberi fasilitas-fasilitas lainnya untuk mempermudah kerjasama antara Ramajunan dan Hardy. Terlihat dari perkataan Hardy:

Hardy: "Baik. Ramanujan, kami putuskan, demi kebaikan semua orang kau harus ikuti beberapa kuliah.”

Perkataan hardy tersebut mengartikan, bahwa segala keperluan yang bersangkutan dengan penelitian ini. Maka segala kebutuhan Ramajunan akan ditanggung oleh universitas. Mulai dari mengikuti perkuliahan secara gratis, dan fasilitas lainnya. Dengan begitu akan mempermudah timbal balik antara ramanujan dan universitas.

Pada umumnya, cara yang digunakan para cendekiawan dalam mengkaji Timur adalah membiarkan mereka (Timur) berbicara atas nama mereka sendiri, untuk menampilkan diri mereka sendiri, tetapi hanya sampai batas-batas tertentu dan dengan cara-cara tertentu pula (Said, 2010: 456-457). 
Dimulai ketika Ramajunan mengirmkan surat yang ditujukan kepada Hardy (scene 6), hingga akhirnya Hardy merasa penasaran dengan pengetahuan yang dimiliki oleh Ramajunan. Yang pada akhirnya membuat Hardy memutuskan untuk mengundang Ramajunan ke universitas Cambridge (scene 7). Serta Ramajunan menunjukkan hasil dari temuan-temuan riset analisis matematika yang dilakukannya sendiri. Ramajunan berusaha menampilkan dirinya sendiri ke Barat, lalau Barat yang direspon oleh Hardy dan Littlewood membiarkan Ramajunan menampilkan temuannya dengan cara mengundang Ramajunan untuk datang ke universitas Cambridge. Ramajunan hanya diperbolehkan menampilkan temuannya, karena selain itu Barat tidak tertarik. Karena mereka merasa mereka orang-orang yang terpelajar, maka mereka hanya tertarik dengan ilmu pengetahuan.

\section{Scene 8}

Perjalanan Ramjunan untuk menuju sebuah publikasi tidaklah mulus. Ramajunan sering mendapatkan hinaan serta kekerasan yang dilakukan oleh Barat. Perlakuan tersebut mereka lakukan karena alasan rasisme, dan rasa iri mereka terhadap Ramajunan.

\section{Denotasi}

Close up digunakan pada gamabar pertama untuk memperjelas mimik wajah Ramajunan, yang terlihat panik. Long shot digunakan pada gambar kedua, untuk memperlihatkan bahwa Ramajunan diikuti oleh 3 orang yang mengenakan baju prajurit barat dari belakang. Dan medium shot digunakan pada gambar ketiga untuk memperlihatkan ramajunan yang sedang tersungkur dan ditumpahi sayuran.

\section{Konotasi}

Dilihat dari percakapan Ramajunan dan penjual bahan makanan dan adanya orang yang mengenakan baju prajurit, menandakan bahwa sedang terjadi perang. Para prajurit mengikuti Ramajunan dari belakang sembari meneriaki Ramajunan dan berkata:

Prajurit:Ibunya lupa mengiriminya surat. Lihat siapa itu, si hitam jenius! Percaya tidak, mereka tugasi kita selagi ia di sini dalam kemewahan! Mau ke mana kau? Kau si hitam penumpang. Aku bicara padamu. Hei. Ini negeri kami. Jangan lupakan itu.

Setiap pernyataan yang dibuat oleh orientalis-orientalis atau manusiamanusia kulit putih menimbukan adanya jarak yang memisahkan si putih dan nonputih. Atau orang Barat dan orang Timur. Tidak hanya itu, dibalik setiap pernyataan manusisa kulit putih ini terdapat pengalaman, pengkajian, dan pendidikan yang selalu menahan manusia Timur kulit berwarna (nonputih) pada kedudukannya sebagai objek yang dikaji oleh si putih Barat. Karena manusia kulit putih, sebagaimana seorang orientalis, hidup dalam garis ketegangan yang memisahkannya dengan manusia kulit berwarna, maka dia merasa berkewajiban membatasi (ras, bangsa, dan peradaban) antara dia dan objek yang ditelitinya (Saiad, 2010: 350).

Para prajurit barat memanggil Ramajunan dengan sebutan "si hitam jenius" seolah-olah mereka membatasi antara si hitam dan si putih. Perkataan yang dilontarkan oleh prajurit tersebut merupakan sindiran yang mereka berikan kepada Ramajunan. Para prajurit merasa bahwa Ramajunan lah yang harus menjadi penjaga menggantikan para mahasiswa yang ditugaskan menjadi prajurit dadakan. Dan Ramajunan tidak pantas untuk berada di dalam tempat aman, sedangkan mereka berjaga untuk kampus. Mereka memandang rendah ramajunan dari warna kulit. Mereka merasa bahwa 
orang-orang kulit hitam tidak pantas mendapatkan perlakuan istimewa. Sedangkan yang pantas, untuk mendapatkan perlakuan istimewa adalah orang-orang berkulit putih. Mereka merasa bahwa orang-orang kulit putih bisa melakukan hal yang mereka sukai terhadap orang-orang berkulit putih.

Akan tetapi apa yang tampaknya paling mempengaruhi Orientalisme sehingga ia mampu bertahan hingga saat ini adalah rasa permusuhan yang terlihat jelas dari orang-orang Barat yang berurusan dengan Timur, beragam tigkatan inferioritas dan superioritas yang ditampilkan-nya, dan jenis sifatsifat yang khas Timur dan Barat sengaja dipisah secara geografis dan imajinatif yang terus bertahan dan dipertahankan selama berabad-abad lamanya (Said, 2010: 309). Oleh karena itu, menjadi manusia kulit putih bukan hanya merupakan suatu kenyataan, melainkan juga sebuah gagasan. Ia melibatkan suatu kedudukan yang dapat dinalar berdasarkan pandngan dunia "putih" dan "non-putih". Tidak hanya itu, menjadi manusia kulit putih berarti menjadi manusia yang harus berbicara dengan cara tertentu, berprilaku dengan aturanaturan tertentu, dan bahkan merasakan hal-hal tertentu untuk kemudian mengabaikan hal-hal lain. Menjadi manusia kulit putih juga mengharuskan adanya penilaian-penilaian, pertimbangan-pertimbangan, dan gerakgerik khusus. Menjadi manusia kulit putih dapat diandaikan sebagai bentuk botoritas yang harus dipenuhi oleh orang-orang non-putih, bahkan oleh kaum putih sendiri (Said, 2010: 348).

Rasa permusuhan yang ditunjukkan oleh para prajurit terhadap Ramajunan karena ras yang dimiliki oleh Ramajunan. Mereka merasa bahwa orang-orang berkulit hitam sebagai bentuk inferioritas. Sedangkan orangorang berkulit putih merasa merekalah orang-orang superioritas. Bagi mereka, orang-orang berkulit putih adalah orangorang yang berkedudukan lebih tinggi dibandingkan orang-orang berkulit hitam. Dan prajurit merasa bahwa orang yang berkedudukan rendah seperti Ramanujan, tidak pantas unuk mendapatkan rasa aman dan perlakuan istimewa. Sedangkan mereka yang berkedudukan lebih tinggi, ditugaskan untuk menjaga keamanan. Mereka menghakimi Ramajunan karena ras yang dimiliki oleh Ramajunan. Prajurit meremehkan Ramajunan, dan menghajar Ramajunan serta membuang sayuran yang telah dibeli oleh Ramajunan ke tubuh Ramajunan. Sifat yang ditunjukkan oleh para prajurit tersebut adalah superioritas.

\section{Scene 9}

Meskipun Ramajunan mendapatkan perlakuan buruk dari oangorang Barat. Tetapi Ramajunan berhasil menyelesaikan pembuktian yang dituntut oleh Hardy. Hardy pun membawanya kepada Major, agara Major bisa merekomendasikan Ramajunan untuk menjadi seorang fellow (gelar kehormatan yang dicapai melalui pengakuan dari sesamanya pers atas integritas pribadi).

\section{Denotasi}

Medium shot digunakan pada gambar 1 dan 2. Pada gambar 1 medium shot digunakan untuk menunjukkan bahwa Hardy sedang mengobrol dengan major. Dan pada gambar 2 medium shot juga digunakan untuk memperjelas posisi duduki Hardy diatas meja dan menampilkan major.

\section{Konotasi}

Hardy menunjukkan hasil pembuktian Ramajunan kepada Major. Hardy melihat kebelakang, agar major lebih fokus melihat pembuktian yang dilakukan oleh Ramajunan. Setelah major memberikan reaksinya atas 
pembuktian Ramajunan, Hardy langsung duduk di meja untuk meyakinkan major. Posisi duduk Hardy, membuat Major lebih memperhatikan Hardy dan lebih meyakinkan.

Major: "Tuhanku. Dia berhasil. Dia benar-benar berhasil”.

Hardy: "Sekarang ia harus jadi seorang Fellow."

Major: "Bersikaplah pragmatis, Hardy. Ia hanya akan gagal lagi."

Hardy:”Tidak jika kau membantu, ia takkan gagal. Selain itu, ada cara lain. Jika ia seorang... Jika ia punya seorang Fellowship Kerajaan..." India!"

Major: "Seorang FRS? Dia orang

Hardy:"MacMohon, dengarkan aku. Dia sangat butuh ini."

Tetapi para cendikiawan Timur yang melanjutkan pendidikannya di Barat ini tetaplah berperan tak lebih sebagai informan pribumi saja. Dan, memang, inilah peranannya di Barat. Ada juga indikasi-indikasi lain mengenai bagaimana dominasi budaya semacam ini dipertahankan, baik oleh persetujuan Timur sendiri. Jadi di Timur selain terjadi suatu penyerapan intelektual atas citra-citra dan doktrin-doktrin Orientalisme, terjadi juga pengukuhan orientalisme dalam pertukaran ekonomi, politik, dan sosial(Said, 2010: 503-508).

Hardy mengundang Ramanujan untuk menunjukkan kemampuannya dalam bidang matematika, dengan syarat Ramajunan harus tinggal di Barat dan menunjukkan pembuktiannya terhadap teori-teori yang ditemukan oleh Ramanujan. Kemudian pembuktian yang dihasilkan oleh Ramanujan dibawa Hardy untuk ditunjukkan ke Major. Major pun terkejut, dan ketika Hardy mengusulkan Ramanujan untuk menjadi fellow Major tidak menyetujuinya. Karena Major merasa, bahwa Ramanujan berada di universitas Cambridge tidak lebih hanya untuk pembuktian. Dan hasil pembuktian tersebut, sebagai informasi yang bermanfaat untuk Barat.

Barat beranggapan bahwa Timur adalah India yang, tentu saja, adalah milik orang Inggris dan perlu ditaklukan (Said, 2010: 261). Major merasa Ramajunan tidak akan berhasil jika ia direkomendasikan menjadi fellow. Karena ras yang dimiliki oleh Ramanujan dan yang pantas menjadi fellow hanyalah orang-orang yang berasal dari Barat dan berpendidikan.

Masalah-masalah seperti ini hanyalah semata-mata sebagai cara negara Barat untuk memperjelas kepentingan-kepentingan mereka yang lebih besar, yakni menjadikan Timur sebagai pokok kajian ilmiah yang selalu diombang-ambingkan oleh Barat (Said, 2010: 296). Ketidak seimbangan antara Timur dan Barat semacam ini jelas merupakan akibat dari pola sejarah yang selalu berubah (Said, 2010: 314-315). Major merasa, bahwa mereka berkepentingan untuk meneliti hasil teori-teori yang dimiliki oleh Ramanujan. Karena bagi mereka Ramanujan hanyalah seorang informan yang berasal dari Timur. Dan apabila seorang informan mempunyai kedudukan yang lebih tinggi, maka mereka tidak akan bisa lagi mendapatkan informasi yang dibutuhkan. Yaitu informasi berupa teori-teori ataupun penemuan-penemuan baru dalam bidang matematika. Oleh karena itu ketidakseimbangan seperti itu terus dipertahankan agar, Ramanujan tetap berada pada posisinya yaitu seorang informan.

\section{Scene 10}

Setelah melewati perjalanan yang panjang, akhirnya Ramanujan berhasil diangkat menjadi fellow. Keberhasilan Ramanujan tersebut, tidak lepas dari dukungan Hardy. Meskipun pada 
awalnya, Hardy tidak menyukai Ramanujan. Tetapi karena Hardy merasa cocok bertukar pikiran dengan Ramanujan, maka Hardy pelan-pelan mulai mendukung Ramanujan untuk menjadi fellow. Tidak lama setelah Ramanujan diangkat menjadi fellow, Ramanujan meninggal karena sakit yang dideritanya. Hardy pun mengundang para fellow untuk berkumpul di aula serbaguna.

\section{Denotasi}

Hardy berdiri di atas mimbar, dan Hardy beserta para fellow yang hadir di dalam aula serbaguna menggunakan setelan jas berwarna hitam.

\section{Konotasi}

Hardy dan para fellow yang hadir, mengenakan pakaian serba hitam sebagai bentuk penghormatan. Atau sebagai tanda duka untuk Ramanujan. Hardy mengungkapkan rasa kehilangan atas meninggalnya Ramanujan

"Sulit diucapkan kata-kata apa yang menjadi hutang saya pada Ramanujan. Orisinalitasnya menjadi sumber sugesti yang konstan bagi saya bahkan sejak pertama bertemu dengannya. Dan kematiannya adalah goncangan terburuk yang pernah saya rasakan. Tapi kini saya katakan pada diri sendiri saat mendapat tekanan, dan mencoba memaksa diri mendengarkan orang-orang membosankan dan angkuh, Aku sudah menyelesaikan hal yang tak pernah kau selesaikan. Aku bekerjasama dengan Littlewood dan Ramanujan "pada sesuatu yang berkaitan dengan kesetaraan."

Dari pernyataan Hardy tersebut, terlihat bahwa Hardy mengakui kemampuan Ramanujan. Hardy merasa bahwa selama ini mereka bersifat angkuh dan egois terhadap Ramanujan. Dan terlalu menghakimi Ramanujan karena ras yang dimiliki oleh Ramanujan. Padahal dalam bidang ilmu matematika, Ramanujan setara dengan mereka orang-orang Barat. Dan Hardy merasa bahwa ilmu yang dimiliki oleh Ramanujan setara dengan mereka.

\section{Pembahasan}

Said mengatakan:

"Anyone who teaches, writes about, or researches the Orient -and this applies wheter the person is an anthropologist, sociologist, historian, or philologist-eithe in its specisfic or its general aspects, is an Orientalist, and what he or she says does is Orientalism" (setiap orang yang mengajar, menulis atau sebagai peneliti tentang ketimuran, -hal ini berlaku pada setiap orang baik sebagai seorang antropolog, sosiolog, sejarawan atau pengkaji masalah filologi -dari aspek umumatau sepesifik merupakan seorang orientalis, dan siapapun orangnya, apa yang dilakukan oleh pria maupun wanita tersebut dinamakan sebagai orientalis)"(Carey,2001dalamhttp://www .Wmich. edu/ dialogus/texts/orientalism.htm).

Secara singkat dapat disimpulkan bahwa Orientalisme adalah pandangan Barat terhadap Timur. Sedangkan orangorang yang memiliki pandangan tersebut disebut sebagai Orientalis. Orientalisme dapat dikatakan hanya merupakan imajniasi-imajinasi para orientalis. Sedangkan oksidentalisme adalah disiplin ilmu yang mengkaji tentang Barat dan kebaratan. Ilmu ini muncul Karen kesadaran akan ingin bebasnya dari keterkunkungan intelektual dan kebudayaan karena hagemoni dan control Barat. Menurut Sou'yb (dalam Rahmad, 2014: 22) Oksidentalsime secara bahasa bersasal dari Bahasa Yunani, occident, yang berarti barat (secara harfiah), dunia belahan barat (secara geografis), danbangsa-bangsa di Barat (secara etnologis). Secara konseptual berarti termasuk bangsa dan 
lingkungannya. Secara geografis berarti meliputi wilayah : nordik (Denmark, Swediya, Finnlandia, Norwegia, dan Siceland), mediterania (Yunani, Itali, Cyprus, Malta, dan lain-lain), semenanjung Liberia (Spanyol dan Portugal), Australasia (Australia, New Zealand, Caledonia, dan New Hybrides), dan Rusia termasuk juga Asia tengah.

Secara etimologis, oksidentalisme merupakan suatu disiplin ilmiu yang mempelajari tentang Barat dan kebaratan dari perspektif non-Barat. Oksidentalisme merupakan suatu gejala baru yang mucul pada akhir decade abad 20. Pada saat itu juga baru sebuah wacana atau ide yang belum diaplikasikan dalam sebuah bentuk ilmu yang mapan (Sholihin, 2008: 252).Tidak seperti Orientalisme, Oksidentalisme yang usianya masdih muda, masih banyak bentuk penemuannya itu suatu hal yang tak lebih hanya sebatas sebagai isme biasa. Karena masih belum mapan, Oksidentalisme ini ada yang menyebutnya ini hanya sebagai paham yang seperti paham lainnya. Dalam oksidentalisme belum ada teoritikal yang mapan. Masih banyak yang diambil dari Barat, padahal Oksidentalisme adalah kajian tentang Barat dan ke Baratan. Berbeda dengan Orientalisme yang sudah mapan, yang mempunyai makna diskurtif, Oksidentalisme hampir belum pernah disebut sebagai duatu disiplin ilmu.

Sebelum dicetuskan oleh Hassan Hanafi sebagi suatau keilmuan, Oksidentlisme meruppakan suatu gagasan yang lahir bagitu saja yang bersiafat reaktif. Kajian Oksidentalisme ini masih mempunyai kelemahan yang mendasar. Pertama, kajian-kajiannya masih merupakan produk Barat. Kedua, kajian-kajian tersebut merupakan promosi peradaban "yang lain” yang kurang daya kritisnya. Oksidentalisme juga lahir karena dorongan emosional dari berbagai kekalahan Barat yang dialami oleh Timur. TImur tak hanya menjadi objek, bahkan sudah menjadi sebuah "karier" bagi orang Barat, sehingga dalam hal ini Orientalisme merupakan suatu yang sengat penting untuk mendukung karier merekea itu(Sholihin, 2008: 252).

Hassan Hanafi membina gagasan oksidentalisme secara konseptual dan historical sebagai peganga umat Islam atau Negara Islam dalam menghadapi hegemoni Barat dalam konteks budaya. Oksidentalisme ini merupakan suatu kajian yang memutar-balikkan suatu realitas bangsa yang tadinya merupakan subjek pengkaji (bangsa Barat/The Other) menjadi objek kajian, dan bangsa yang tadinya merupakan objek kajian (bangsa Timur/ ego) menjadi subjek pengkaji (Rahmad, 2014: 22).Oksidentalisme bersikap netral dan sangat bertolak belakang dengan orientalisme yang didominasi refleksi struktur kesadaran Eropa. Oksidentalisme bukan untuk imperialism, tetapi untuk membebaskan diri dari pengaruh pihak lain agar terwujud kesetaraan antara dunia Timur dan dunia Barat (Hanafi, 2000: 18)

Kebudayaan kontemporer juga mngakibatkan seseorang tak mampu lagi berintelektual tanpa baerafiliasi dengan salah satu madzhab kontemporer, madzhab the other, seperti sosialisme, marxisme, dan sebagainya. Dengan adanya "penjagaan identitas" dan pengafiliasi-an intelektual terhadap budaya kontemporer, tak disadari, sang ego telah menempatkan diri pada tempat petikaian. Ego pecah karena the other. Memang salah satu dampak, atau memang hal ini merupakan tujuan dari orientalisme, adalah memecah belah ego. Dulu juga pernah pecah, namun hal itu timbul dari diri ego sendiri. Pengaruh dari westerniasasi mnyebabkan semua orang mencari identitas masing-masing, 
orisinalitas sendiri, kebudayaann negara hilang. Hal ini merupakan jembatan emas bagi the other untuk masuk dan mempengaruhinya, membawa kebudayaan the other ke kebudayaan lain(Hanafi, 2000: 18).

Di zaman yang belum modern seperti saat ini, para orientalis mengembangkan atau menyalurkan pemikiran mereka tentang Orientalisme melalui tulisan-tulisan, atau buku, serta artikel. Tetapi di zaman modern seperti saat ini, para orientalis tidak banyak yang menggunakan tulisan, buku, atau artikel. Tetapi para orientalis menunjukkan nya melalui film. Salah satu film yang menunjukkan Orientalisme tersebut adalah film The Man Who Knew Infinity. Film The Man Who Knew Infinity merupakan film yang menceritakan tetang ilmuan atau penemu Timur dalam bidang matematika. Tetapi karena film tersebut di produksi Barat, maka film tersebut lebih menonjolkan kesuperioritasan Barat. Film tersebut sangat jelas menampilkan bagaimana imajinasi-imajinasi Barat terhadap Timur. Dari mulai perkataan, serta perlakuan yang ditampilkan Barat di film tersebut. Sang orientalis ingin menunjukkan bahwa Barat lah yang memegang kekuasaan atas Timur. Dan Timur merupakan orang-orang lemah, yang berada di bawah Barat. Serta pengetahuan yang dimiliki oleh Timur tidak setara dengan pengetahuan yang dimiliki oleh Barat. Meskipun pada akhirnya mereka diakui oleh Barat, akan tetapi pengakuan tersebut tidak lepas dari pengaruh orang-orang Barat di dalamnya.

Padahal pada kenyataannya banyak orang-orang Timur yang memiliki kemampuan serta kepintaran di atas Barat. Tetapi karena Orientalisme merupakan imajinasi-imajinasi Barat terhadap Timur, sang Orientalis sengaja mencari celah untuk menampilkan kesuperioritas mereka terhadap Timur. Dan mungkin, sang Orientalis merasa cocok dengan perjalanan yang ditempuh oleh salah satu ilmuan Timur yaituSrinivasa Ramanujan. Padahal belum tentu semua yang dialami oleh Ramajunan dalam film tersebut adalah benar. Akan tetapi karena imajinasi yang dimiliki oleh sang Orientalis, maka film tersebut diproduksi dengan superioritas Barat di dalamnya.

Banyak ilmuan atau penemu Timur lainnya yang pengetahuan atau kepintarannya lebih unggul dibandingkan Barat. misalnya saja dalam bidang ilmu kedokteran. Sekitar tahun 1000, seorang dokter Al-Zahrawi mempublikasikan 1500 halaman ensiklopedia berilustrasi tentang operasi bedah yang digunakan di Eropa sebagai sumber referensi medis pertama pada 500 tahun berikutnya. Di antara sekian banyak penemuan, Al Zahrawi dilaporkan melakukan operasi caesar pertama di dunia. Zahrawi yang menggunakan larutan usus kucing menjadi benang jahitan, sebelum menangani operasi kedua untuk memindahkan jahitan pada luka. Dia juga yang dilaporkan melakukan operasi caesar dan menciptakan sepasang alat jepit pembedahan. Banyak instrumen bedah modern didesain sama persis seperti yang pernah dirancang pada abad ke-10 oleh seorang ahli bedah Muslim bernama al-Zahrawi ini. Seperti pisau bedah, gergaji tulang, tang, gunting halus untuk bedah mata dan banyak dari 200 instrumen yang ia rancang akan kita kenali dalam peralatan kedokteran bedah modern

(https://id.wikipedia.org/wiki/Abu_alQasim_al-Zahrawi). Pada abad ke-13, medis Muslim lain bernama Ibn Nafis menggambarkan sirkulasi darah 300 tahun sebelum William Harvey menemukannya. Dokter Muslim ini juga menemukan obat bius dari campuran 
opium dan alkohol dan jarum berongga untuk menyedot katarak dari mata, ini merupakan sebuah teknik luar biasa yang masih digunakan sampai sekarang.

Masih banyak lagi ilmuan atau penemu-penemu Timur yang lebih unmggul dibandingkan Barat. Akan tetapi karena superioritas yang dimiliki Barat, serta kekuasaan yang dimilikinya. Barat berusaha menutupi kenyataan tersebut, dan mengembangkan imajinasiimajinasi mereka terhadap Timur. Agar mereka bisa menanamkan ideologi tentang Barat dan Timur. Dengan maksud, agar Barat tetap berada di atas dan disegani oleh seluruh belahan dunia.

\section{PENUTUP}

Setelah menganalisis data berupa rangkaian scene dalam film The Man Who Knew Infinity dengan mencari makna denotasi, konotasi, dan mitos yang dianggap merepresentasikan orientalisme dalam status sosial pendidikan, maka dapat dirumuskan beberapa hal yaitu:

\section{Makna Denotasi}

Makna denotasi dalam penelitian ini adalah gambaran tentang potret kehidupan orang Timur di Barat. Sehingga, ada gambar serta teks yang menunjukkan perlakuan Barat serta bagaimana Barat memandang dan berbicara terhadap Timur. Antara lain, gambar yang menunjukkan barat melakukan kekerasan terhadap Timur, dan beberapa teks yang menunjukkan ketidak seimbangan antara Timur dan Barat.

\section{Makna Konotasi}

Sehingga, makna konotasi yang terlihat dalam film ini adalah perjuangan yang dilakukan oleh Ramanujan untuk membuktikan bahwa teori yang ditemukannya layak dan pantas untuk dipublikasikan. Dan kepintaran

Ramanujan setara rengan
kepintaran-kepintaran $\begin{array}{r}\text { para } \\ \text { ilmuwan Barat. }\end{array}$
$\begin{aligned} & \text { Meskipun } \\ & \text { Ramanujan }\end{aligned}$
perlakuan buruk di
terintimidasi karenat dan
Barat terhadap Timur, tetapi ia
tetap bertahan dan terus berusaha
serta meyakinkan barat bahwa
teori yang dimilikinya layak untuk
dipublikasikan dan bermanfaat
bagi orang banyak.

Dari scene-scene tersebut dapat diambil kesimpulan bahwa film "The Man Who Knew Infinity” merepresentasikan kekuasaan dan perbedaan status sosial antara Barat dan Timur. Serta bagaimana pandangan Barat terhadap Timur atau disebut dengan Orientalisme. Meskipun mereka (Timur) mempunyai kepintaran yang setara dengan Barat, tetapi tetap saja mereka membuat seolah-olah Timur tidak bisa setara dengan Barat dalam hal pendidikan.

Film "The Man Who Knew Infinity" juga merepresentasikan bahwa segala sesuatu yang diraih oleh Timur tidak lepas dari pengaruh Barat. Padahal pemikiran Timur juga setara dengan Barat dalam bidang pendidikan, tetapi karena yang membuat film tersebut berasal dari Barat. Maka mereka lebih menonjolkan Barat dibandingkan Timur. Sedangkan Timur lebih ditonjolkan dengan bagaimana mereka memandang Timur.

\section{Saran}

Terkait dengan penelitian ini ada beberapa saran yang dapat sampaikan:

1. Sebelum menonton sebuah film, kita harus siap dihadapkan dengan jalan cerita yang akan ditampilkan oleh sutradara sebagai penggambaran realitas yang diinginkan. Karena, film bukan semata-mata pemindahan realitas di hadapan kita yang begitu saja 
dipindahkan ke dalam layar, tetapi ada nilai-nilai yang dimiliki oleh pembuatnya yang ingin ia masukkan. Sehingga realitas itu menjadi sebuah representasi, sebuah gambaran yang sudah dimediasi.

2. Bagi penulis, film ini sudah memenuhi kriteria yang baik untuk sebuah film. Ada unsur hiburan, edukasi, dan juga informasi. Tetapi film tersebut hanya mennjolkan salah satu pihak saja, seharusnya kedua belah pihak harus samasama ditonjolkan.Film ini bisa dijadikan contoh bagi mereka yang ingin membuat film idealis tanpa harus melupakan fungsi film sebagai hiburan.

\section{DAFTAR PUSTAKA}

Barthes, Roland. 1976.The Pleasure of the Text. London: Jonathan Cape.

Roland. 2009. Mitologi (Cetakan

KetigaTerjemahan oleh

Nurhadi dan A. Sihabul

Millah).Yogyakarta: Kreasi

Wacana.

Berger, dkk. 2014. Handbook Ilmu

Komunikasi. Bandung: Nusa Media.

Bignell, Jonathan. 1997. Media

Semiotics: An

Introduction.Manchester and

New York : Manchester

University Press.

Buchori. Menyingkap Tabir

Orientalisme. 2006. Jakarta :

Amzah

Burton, Graeme. Media and Society :

Critical Perspectives. 2005.

England : Open University

Press.

Cangara, Hafied. 2004. Pengantar Ilmu

Komunikasi. Jakarta : Raja

Grafindo Pustaka.

Danesi, Marcel. 2010. Pengantar Memahami Semiotika Media. Yogyakarta: Jalasutra.
Effendy,Onong Uchjana. 2003. Ilmu, Teori dan Filsafat Komunikasi. Bandung : Citra Aditya Bakti.

Fiske, John. 2007. Cultural and Communication Studies: Suatu

Pengantar

Paling

Komprehensif, (terjemahan.Yosal Iriantara dan Idi Subandy Ibrahim, cetakan keempat). Yogyakarta : Jalasutra.

Hall, Stuart (Ed.). 2013. Representation: Cultural Representations and Signifying Practices (2 Edition), London : Sage Publications.

Hanafi, Hassan. 2000. Oksidentalisme : sikap kita terhadap tradsisi Barat. Terj. Jakarta :

Paramsdina

Imanjaya, Ekky. 2004. Who Not: Remaja Doyan Nonton. Bandung : Mizan Buaya Kreativa.

Kamus Besar Bahasa Indonesia. 2008. Pusat Bahasa Departemen Pendidikan Nasional.Jakarta: Balai Pustaka.

King, Richard. Agama Orientalisme dan Poskolonialisme (terj.). 1999. Yogyakarta : Qalam

Kriyantono, Rachmat. 2007.Teknik Praktis Riset Komunikasi. Jakarta: Kencana.

Moekijat. 1996. Teori Komunikasi Massa. Jakarta : Erlangga

Mudjiyanto, Bambang \& Emilsyah Nur. 2013. Semiotika Dalam Metode Penelitian Komunikasi, Volume 16 No. 1. Makassar: Balai Besar Pengkajian dan Pengembangan Komunikasi dan Informatika Monaco, James. 1997. Cara Menghayati Sebuah Film. Jakarta : Yayasan Citra Noviani, Ratna. 2002.Jalan Tengah Memahami Iklan. Yogyakarta : Pustaka Pelajar.

Pratista, Himawan. 2008. Memahami Film. Yogyakarta: Homerian Pustaka. 
Rahmad, Mohammad Saleeh. 2014 .

Oksidentalisme dalam Sastera

Melayu : sebelum merdeka

hingga era Mahathir

Muhammad. :ITBM

Said, Edward W. 2010. Orientalisme :

Menggugat Hegemoni Barat

Dan Mendudukan Timur

Sebagai Subjek (Penerjemah

Achmad Fawaid). Yogyakarta : Pustaka Pelajar.

Selby, Keith dan Ron Coedery.1995.How to Study

Television.London:Mc Millisan.

Sobur, A. 2004. Semiotika komunikasi.

Bandung : Remaja Rosdakarya

.2013. Semiotika komunikasi.

Bandung : Remaja Rosdakarya.

Sholihin,Muhammd. 2008. Filsafat dan

Metafisika dalam Islam.

Yogyakarta : Narasi

Stam, Robert. New Vocabularies in Film

Semiotics : Structuralism,

PostStructuralism, and

Beyond. 1992. London :

Routledge.

Sturken, M. and Lisa Cartwright. 2001.

Practices of Looking, an Introduction to Visual Culture. New York: Oxford University Press.

Tinarbuko,Sumbo. 2008. Semiotika Komunikasi Visual. Yogyakarta : Jalasutra

West, Richard. Lynn H.Turner. 2007. Pengantar Teori Komunikasi. Jakarta : Salemba Humanika.

Wibowo, Fred. 2007.Teknik Program Televisi. Yogyakarta : Pinus Book Publisher.

\section{Jurnal}

Jouhki, Jukka. 2006. Orientalism and India. J@rgonia-Elektroninen Julkaisusarja. ISSN 1459-305X

Lary,Diana.2006. Journal of Kanada Historical Association de /
Revue lasociété historique du Kanada. vol. 17.

Jatmiko, Inoki Wasis. 2011. Kritik Terhadap Orientalisme: Studi Komparatif Pemikiran Edward Said \& Musthofa Al A'zami. Thesis Universitas Muhamadiyah Surakarta: Surakarta.

\section{Sumber Lain}

Carey, 2001 dalam http://www.wmich.edu./dialogu es/texts/orientalism.htm (diakses pada tanggal 7 Desember 2016)

http://idbeasiswa.com/perbedaanscholarship-fellowship-dan-grant(diakses pada tanggal 3 Juni 2017)

http://www.Pengertianmenurutparaahli.n et/pengertian-rasis-dan-fasis (diakses pada tanggal 3 Juni 2017)

http://nationalgeographic.co.id/berita/20 10/11/makna-jabat-tangan (diakses pada tanggal 3 Juni 2017)

https://id.wikipedia.org/wiki/Universitas _Cambridge (diakses pada tanggal 3 Juni 2017)

http://www.bolehmerokok.com/persepsicangklong (diakses pada tanggal 3 Juni 2017)

http://www.Pasramanganesha.sch.id/201 4/09/makna-tilak-bindi-didahi.html (diakses pada tanggal 3 Juni 2017)

https://id.wikipedia.org/wiki/Kurta (diakses pada tanggal 3 Juni 2017)

https://id.wikipedia.org/wiki/Tempat_su ci_Hindu (diakses pada tanggal 3 Juni 2017)

https://id.wikipedia.org/wiki/The_Man_ Who_Knew_Infinity_film (diakses pada tanggal 15 April 2017) 
https://id.wikipedia.org/wiki/Srinivasa_

Ramanujan (diakses pada tanggal 15 April 2017)

http://www.muvila.com/film/artikel/theman-who-knew-infinity-ujikesabaran-sang-sutradara150918z.html (diakses pada tanggal 15 April 2017)

https://id.wikipedia.org/wiki/Dev_Patel (diakses pada tanggal 15 April 2017)

https://id.wikipedia.org/wiki/Jermy_Iron s (diakses pada tanggal 15 April 2017)

https://en.wikipedia.org/wiki/Devika_Bh ise (diakses pada tanggal 15 April 2017)
https://id.wikipedia.org/wiki/Toby_Jones (diakses pada tanggal 15 April 2017)

https://id.wikipedia.org/wiki/Stephen_Fr y (diakses pada tanggal 15 April 2017)

https://en.wikipedia.org/wiki/Jere my_Northam (diakses pada tanggal 15 April 2017)

https://en.wikipedia.org/wiki/Kevin_Mc Nally (diakses pada tanggal 15 April 2017)

Undang-undang Republik Indonesia no.8 tahun 1992 tentang Perfilman. Bab I pasal 1 ayat 1 